\title{
Ecological Capability of Land Use Planning for Rural Development
}

\author{
${ }^{1}$ J Nouri, ${ }^{2}$ R Sharifipour and ${ }^{1}$ A. A. Babaei \\ ${ }^{1}$ Deptartment of Environmental Health Engineering, School of Public Health and Center for \\ Environmental Research, Tehran University of Medical Sciences, Tehran, Iran \\ ${ }^{2}$ Department of Environmental Management, Graduate School of the Environment, Science and Research \\ Campus and Academic Staff Savad kooh Islamic Azad University, Iran
}

\begin{abstract}
Execution of development and creation of appropriate points for rural development without considering ecological capability will result in the appearance of several environmental, economic and social problems. This research is done in an analysis approach frame of a system with the aim of choosing the most suitable location for rural development in Abadeh with an area of 22,000 km2. In 2002 by applying geographic information system (GIS) precious tools. Based on the above objective, ecological resources of concerned area were recognized and surveyed. The obtained data changed into digital figures and together with the other descriptive data were shifted to Arc/Info and Arcview systems for the purpose of creation of data base. Based on specific ecological models of Iran and special conditions of the area and by using structured query language (SQL) in Arcview, the ecological capability of concerned area for rural development was determined. By considering current natural limitations, such as limited severe earthquake danger in central areas, limitation of flood danger in some of the central and western areas, development of evaporating deposits and salt domes in east and precipitation under $500 \mathrm{~mm}$ in the studied area, no suitable place for the first grade rural development was found. However, it showed capability for second-grade rural development aspect. This area includes $3.8 \%$ of total area of the studied place. For improving present management in the studied region, it is recommended that in future development of the region, offered appropriated points while emphasizing on the land having low production capability to be considered.
\end{abstract}

Keywords: Environment capability evaluation, Geographical Information System, Ecological model, Abadeh, System analysis approach.

\section{INTRODUCTION}

When a rural or a residential area is formed into the two interactions, first, the formed area causes to generate a reaction toward environment (changing the natural waterway may be caused the erosion of the soil or soil becomes polluted by wastewater), second; environment has a reaction toward this area (exposed to earthquake or flood). So before the beginning of development, it is better to select the suitable developing site in terms of ecological capability in order to prevent reduction of natural resources, which may happen for the reason of illogical usage.

The objective of this research is the prevention of excessive reduction of natural resources that was occurred due to improper use of the environment. For instance, based on performed studies by FAO, it is estimated that from 1800 million Hectares cultivation land, only $8 \%$ is under application for agricultural purposes in developing countries, whereas $92 \%$ is used for other applications ${ }^{[1]}$. Excessive reduction of natural resources, industrial and economical development together with population growth, with the possibility for doubling by the year $2050^{[7]}$, is the reasons for critical situation and destruction of the earth. By population growth and industrialization of the society that is imbalanced with limited resources of the environment, the organic localization of the centers people settlement or activities shall not respond to material and spiritual requirements of the human. Even economical localization shall unsteadily decrease environmental resources. In this regard, land use planning is a kind of long-term planning that considers the land as a determined factor in supplying development goals. Land use planning based on regulations with permanent and suitable return view, according to the qualitative and quantitative capabilities and talents for different use of human from the land, shall render type of utilization.

Thus waste of natural resources and ruining of the environment will be stopped. In ecological evaluation, GIS is quickly becoming data management standard in planning the use of land and natural resources. Virtually all environmental issues involve map-based data, and real world problems typically extend over relatively

Corresponding author: J Nouri, Dept. of Environmental Health Engineering, School of Public Health and Center for Environmental Research, Tehran University of Medical Sciences, Tehran Iran 
large areas. GIS links observations and measurements to specific locations and specifies the relationships between data points. GIS can pull together Very different data types and allows quantitative analysis at the scale of landscapes or entire region. For example, information on soils, hydrology and vegetation might be combined in analysis of wildlife strategy for restoration of degraded ecosystems. Nowadays, GIS has become an indispensable tool for land and resource managers ${ }^{[3,6]}$. This research is performed at Abadeh area in Fars Province of Iran in 2002 for evaluation purpose of ecological capability of rural development with the aim of optimization management of the land.

\section{DATA AND METHODOLOGY}

The surface area of studied area is about $22,000 \mathrm{~km}^{2}$ that is located in central and south part of Iran (Fig. 1). This area is limited in $31^{\circ}, 40^{\prime}$ (north) to $30^{\circ}, 45^{\prime}$ (south) of latitude and $51^{\circ}, 50^{\prime}$ (west) to $54^{\circ}, 5^{\prime}$ ' (east) longitude. The main high place to be mentioned is Sephid Mountain with the height of $3333 \mathrm{~m}$. This area, due to vicinity to Shiraz,Yazd and Esfahan and having other capabilities such as water supply potential from aquifers, rivers and plains have agricultural capabilities for settlement of people. Thus, it should be cleared that where such development is performed, the natural resources should be preserved carefully.

In the present research, for achieving general goals of the plan, by studying and assessment of the elements and common techniques of planning and management, GIS tools and planning and management combination model ${ }^{[2,4,5]}$ were selected for ecological evaluation. Process for evaluation, determination and selection of appropriate rural development points in concerned area included the following steps presented in Fig. 2. In the present research only those resources applied in modeling were studied (Table 1):

\section{Physical resources:}

Landform (slopes, elevation and aspect)

Geology (fault and earthquake probability)

Water resources (aquifers and flood probability)

Hydrogeology

Soil (soil type and erosion)

Climate (climatologically division by Demartin)

\section{Biological Resources:}

Vegetation (type and density)

Wildlife (zoning of protected area)

Slope, aspect and elevation maps were used from topographic maps of Iran Surveying Organization. Hydrology and water resources were obtained from Ministry of Power. The basis for vegetation map was obtained from Planning and Management Organization; soil map was obtained from Water and Soil Research Institute and the information about the protected area in Abadeh was obtained from Department of the Environment in Fars Province. Also, for comparing utilization capability for urban development and land use at the end of the work, present land use map was provided by Iran Surveying Organization, Ministry of Housing and Urban Development. Plan map of Abadeh region and public census maps were provided from Iranian Statistics Center (population points and road networks) and accuracy of obtained maps was estimated with field supervision and similar to map scale were prepared by means of GIS.

\section{Analysis and data classifications:}

Analysis process and data classifications for achieving environmental units at studied area is obtained by overlaying prepared maps with each other and recognition was performed with GIS and final environment maps were completed based on other unstable resources such as hydrology.

Suitable ecological model for evaluation of capability of studied area for rural development in Iranian special ecological models frame ${ }^{[5]}$ was prepared in two-degree value and based on special conditions of concerned region and existing data (Table 2). They were then introduced to Arcview and every environmental unit was compared with special model and capability points for rural development were obtained.

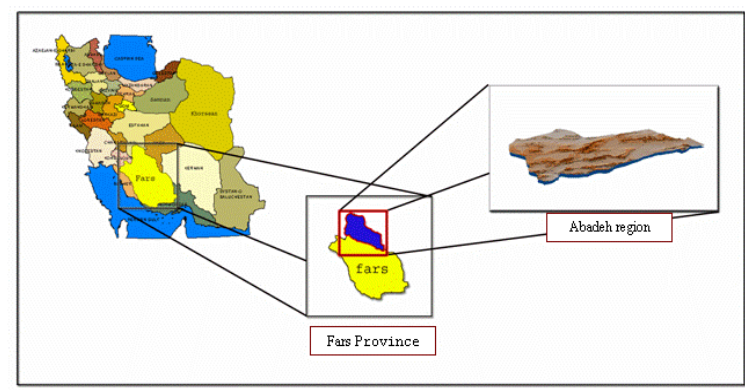

Fig. 1: The position of Abadeh in Fars Province and the map of Iran

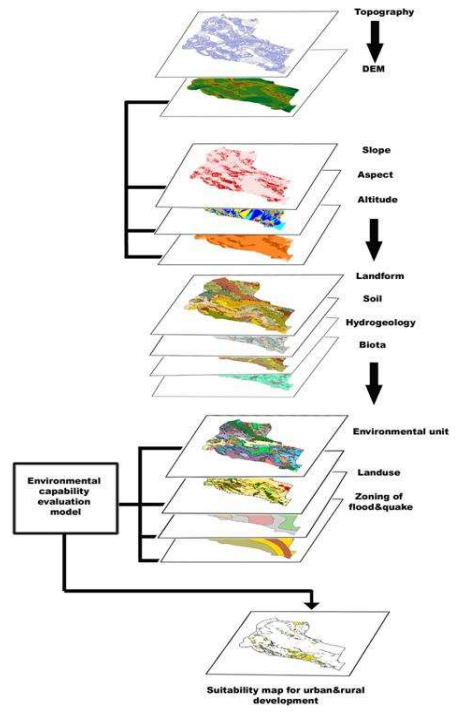

Fig. 2: Slope map in the studied region rural 
development capability evaluation structure of the studied region, using information layers

Table 1: Recognized resources for evaluation of rural development capability

\begin{tabular}{lc}
\hline \multicolumn{1}{c}{ Physical resources } & Resources \\
\hline -Geographical location of the region & Biological resources \\
-Land form & $\begin{array}{c}\text { Type and density vegetation } \\
\text { Slope, aspect and elevation } \\
\text {-Hydrogeology }\end{array}$ \\
-Soil & Zildlife \\
Soil type & \\
Erosion capability & \\
-Climate & \\
-Earthquake probability, fault & \\
-Floor probability & \\
\hline
\end{tabular}

Table 2: Ecological model of rural development

\begin{tabular}{|c|c|c|c|c|c|c|c|}
\hline Parameter & $\begin{array}{l}\text { Slope } \\
(\%)\end{array}$ & $\begin{array}{l}\text { Elevation } \\
\quad(\mathbf{m})\end{array}$ & Aspect & Hydrogeology & Earthquake & Soil & Flood \\
\hline Degree 1 & $0-15$ & $400-1300$ & $\begin{array}{l}\text { East or South } \\
\text { or Plane }\end{array}$ & $\begin{array}{l}\text { Alluvium of down -stream } \\
\text { or field } \\
\text { sediment or carbonate maker }\end{array}$ & $\begin{array}{l}\text { Zoning of very low } \\
\text { and low danger }\end{array}$ & $\begin{array}{c}5 \mathrm{AW} \\
5 \mathrm{~A}\end{array}$ & $\begin{array}{l}\text { Zoning of very } \\
\text { low and low } \\
\text { danger }\end{array}$ \\
\hline Degree 2 & $0-15$ & $1300-2500$ & All of aspects & $\begin{array}{l}\text { Alluvium of down- stream } \\
\text { or field sediment or } \\
\text { carbonate maker }\end{array}$ & $\begin{array}{l}\text { Zoning of very } \\
\text { low, low and } \\
\text { middle danger }\end{array}$ & $\begin{array}{l}3 \mathrm{~A}, 5 \mathrm{~A} 3 \mathrm{~T} \\
\quad, 4 \mathrm{~T}\end{array}$ & $\begin{array}{l}\text { Zoning of very } \\
\text { low, low and } \\
\text { middle danger }\end{array}$ \\
\hline $\begin{array}{l}\text { A: Limita } \\
\text { W: Limita } \\
\text { T: Limitat } \\
\text { 3: Suitabl } \\
\text { 4: Suitabl } \\
\text { 5: It isn't } \\
\text { Note: At t } \\
\text { was not li }\end{array}$ & $\begin{array}{l}\text { of soil fo } \\
\text { of soil fo } \\
\text { f soil fo } \\
\text { irrigatio } \\
\text { irrigatio } \\
\text { er for irr } \\
\text { rea } 82 \%\end{array}$ & $\begin{array}{l}\text { lty and alkaliz } \\
\text { rainage, being } \\
\text { pe and erosior } \\
\text { special condit } \\
\text { ion } \\
\text { the surveys of }\end{array}$ & pasture hav & rived and very deprived com & ression & the param & of vegetation \\
\hline
\end{tabular}

\section{RESULTS AND DISCUSSION}

By using topographic map of concerned area in Arcview in this relation, digital elevation model was obtained (Fig. 3) and slope (Fig. 4), aspect (Fig. 5) and elevation (Fig. 6) were prepared in concerned categorizes for overlaying. Specific ecological model for rural development were adopted and using Structured Query Language (SQL), then capability of each environmental unit were evaluated and mapped (Fig. 7). In the studied area, considering some natural limitations such as rainfall under $500 \mathrm{~mm}$, first grade rural development capability was not observed. However, this area shows capability for second grade rural development. Slope is one of the observed parameters in estimation of appropriate rural development points. Slopes between $0-15 \%$ are suitable that includes $87 \%$ of the area. Also the height of 400 -

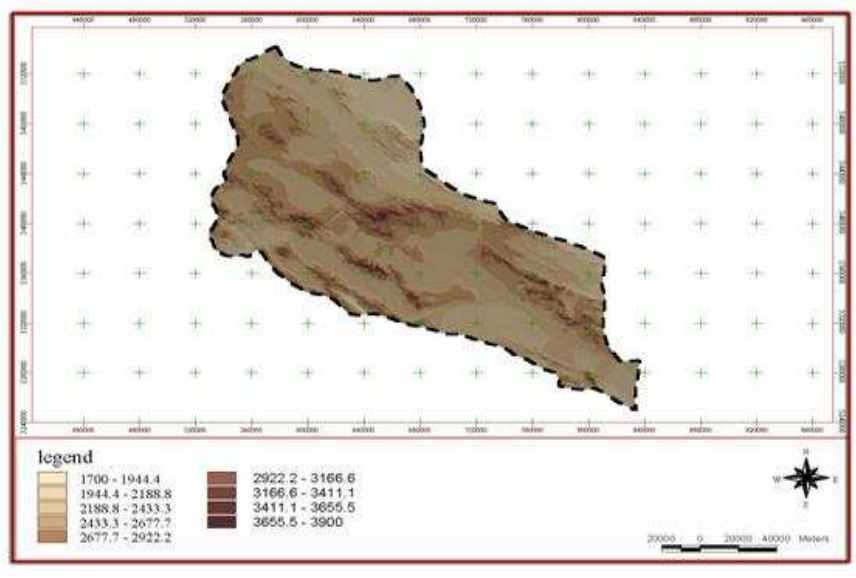

Fig.3: Digital elevation model in the studied region 
$-2500 \mathrm{~m}$ is recognized suitable for such development that covers $77 \%$ of the concerned area. The climate of the region is warm and dry on the southwest part (13\%) and is not suitable for development. Based on hydrogeological maps, the alluviums of down streams and field sediments and Carbonate makers are suitable showing good and average water supply capability with good to average quality that covers $80 \%$ of the area. Also seasonal and permanent rivers such as Rahimi, Izadkhast, Abadeh, Sefid, Oghlid, Bovanat and Sivand rivers are the suitable parameters in observed models. Zoning with average to high danger of earthquake and flood that cover $49 \%$ and $31 \%$, respectively, of the concerned area together with protected area of Basiran and hunting protected area of Tot Siah and Dareh Bagh with an area of about $15 \%$, were not found appropriate for rural development points. From the point of view of vegetation in the studied area, most of the plants are pastures with low and weak accumulation that make no limitation for rural development. Finally at studied region, an area of $3.8 \%$ from total area is recognized for second grade rural development.

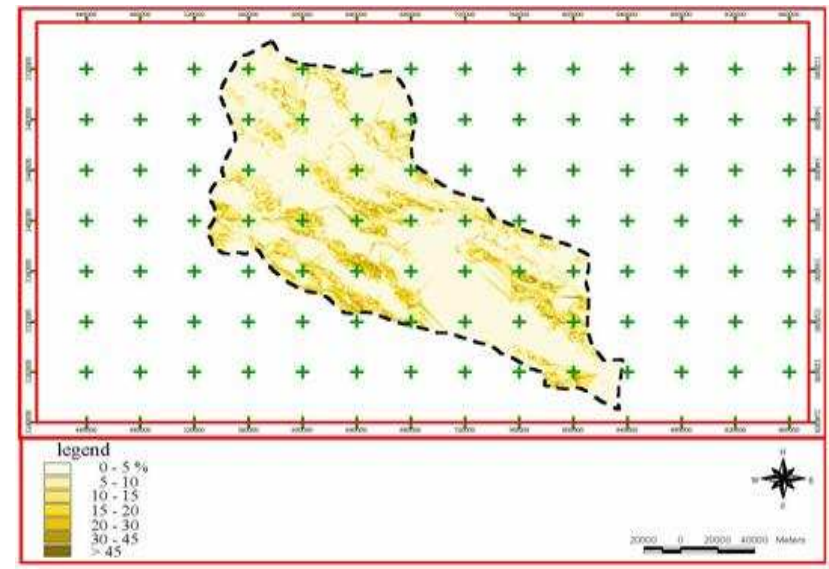

Fig. 4: Slope map in the studied region

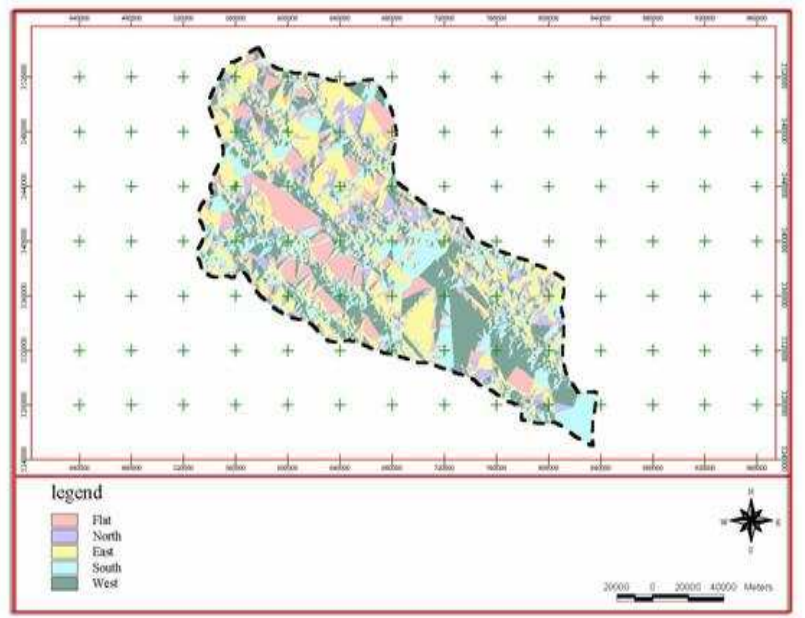

Fig. 5: Geographical aspect map in the studied region

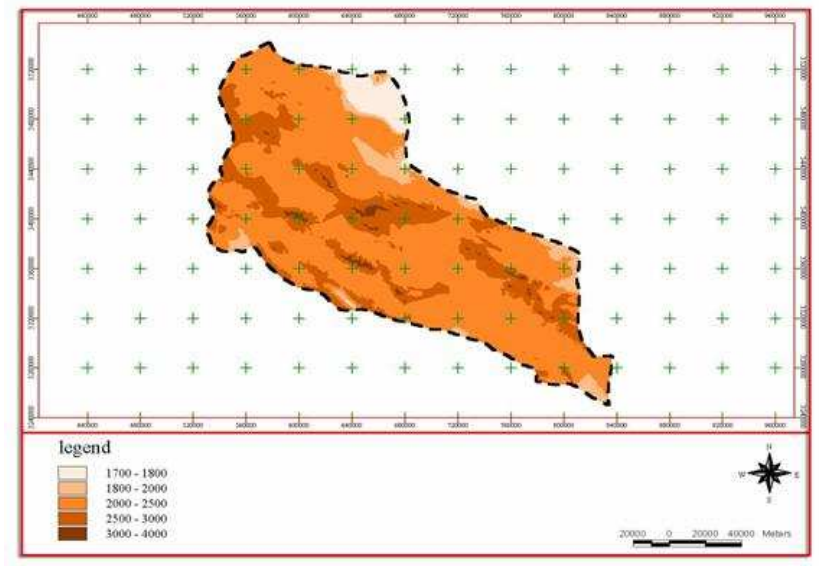

Fig. 6: Elevation map in the studied region

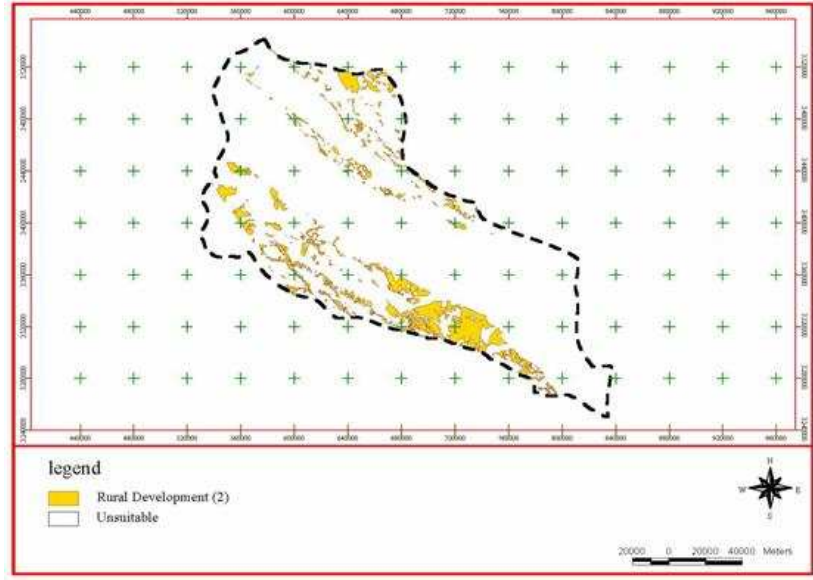

Fig. 7: Appropriate rural development points in the studied region

\section{CONCLUSION}

Rural development capability map was compared with present land use map (Fig. 8). In research area all land use were classified into three groups:

\section{Land use with production return:}

This group consists of the lands including unlimited or slight limited applications in production (agriculture) that is actually utilized or has potential of utilization capability. By execution of a low-expenses civil operation we can get the result and utilize it. Based on production capability, priorities are: agriculture, dry farming and average pastures. Total allocated land for this purpose is $42 \%$ of which about $23 \%$ is for average pasture. On the other word, from total land of concerned region about $20 \%$ has actual potential for economical and agricultural applications and the remaining part is suitable for civil operations with the aim of return increase. 


\section{Land use without return:}

Since a wide part of this region is placed in warm and dry climate and considering the natural limitations, parts of this land has no production potential or lacking from agricultural values or face with severe limitations in this regard. These lands include regions such as high lands, cultivated lands, poor pastures, or Kafter Lake. The main feature of these lands is lacking of plants covering or poor plants covering. This situation in high regions is due to high slope, height, and unsuitable soil conditions and in uncultivated lands they are due to salty conditions and lack of access to surface and underground water resources. Also Kafter Lake in southwest of concerned region is also lacking production return. Total area of this group of lands is about $56.5 \%$ of total studied area. From that $34 \%$ was related to poor pasture area and $10 \%$ to high-level areas.

\section{Residential land use and roads:}

Total area allocated for residential purpose and constructed connecting network is about 2900 ha. That includes only $1.32 \%$ of total area of the region. The considerable point about these lands is placement of urban areas on the lands which are suitable for agricultural purposes. This character can be observed in the main cities. Moreover, about $47 \%$ of Abadeh residential areas are placed around the faults with high and extreme capability for earthquake. It is necessary to consider required arrangements for strengthening against earthquake. In the obtained development map (Fig. 7), because of existing natural limitations in studied area such as high earthquake potential in central areas, flood danger in part of central and western zones, evaporation sediments and salty domes development in east and slope above $30 \%$ in central and western areas, no appropriate point for first grade rural development is obtained. But the concerned area is well capable for second grade rural development which covers $3.8 \%$ of total area. So near to $89 \%$ of urban and more than 635 of inhabitations settled in the 2500-3000 elevation range and $17.3 \%$ of residential area are in more than $30 \%$ slope. Since one of the duties of management of the region is directing method and manner of the use of lands based on capability estimation, it is recommended that in future development of the region, offered appropriate points with emphasizing on the land having low production capability, to be considered.

\section{ACKNOWLEDGEMENTS}

The authors would like to express their thanks to the Maab Consultant Engineers Company for providing basic information and financial supports

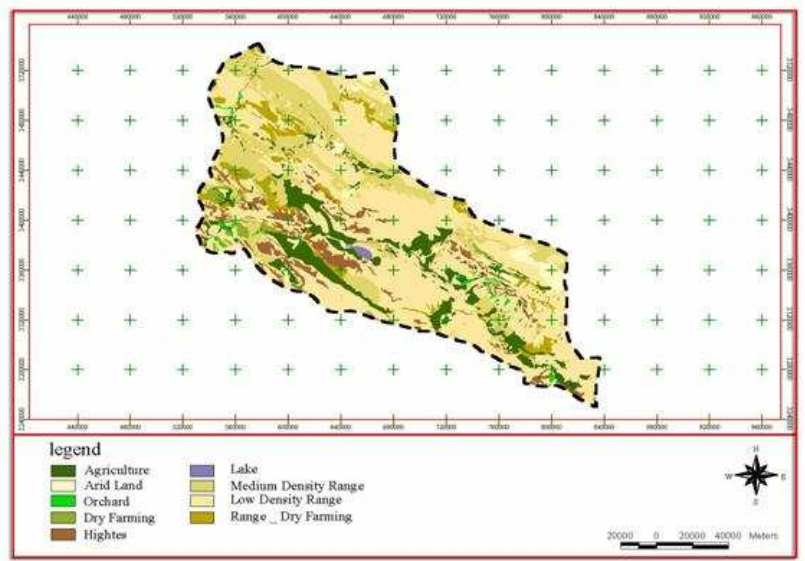

Fig. 8: Land use in the studied region

\section{REFERENCES}

1. Alexandratos, N., 1995. Agriculture: Towards 2010, FAO. Rome and John Wiley, Chi Chester.

2. Armitage, D., 1995. An integrative methodological framework for sustainable environment planning and management. Environ Manage, 19(4): 479-96,

3. Demers, M. N. 1997. Fundamental of geographic information system, New Mexico State University. 1st. Ed.

4. Grant, W. E. 1998. Ecology and natural resource management: reflection from a system perspective management. Ecological Modeling, 108: 67-76.

5. Makhdoum, M. F. 1999. Fundamental of land use Planning, Tehran University Publication.

6. Swanson, E. 2003. Geographic information system (GIS) information enhanced land use planning, Michigan Center for Geographic Information Department of Information Technology.

7. UNFPA. 1992. The state of world population UNFPA/United Nations Population Fund, New York .46.

8. Maab Consultant Engineers. 2002. Comprehensive development plan, north of Fars province, Abadeh region. 